\title{
STUNNING ON ANIMALS SLAUGHTER ON ISLAMIC LAW PERSPECTIVE
}

\author{
Ahmad Yani \\ Cianjur Regency Indonesian Ulema Council, Jl. Sadewata No.108, Bojong, \\ Karangtengah, Kabupaten Cianjur, Jawa Barat, Indonesia, 43281 \\ Email: abu.fajriani@gmail.com \\ Rudi Ahmad Survadi \\ Islamic Education Departement, Sekolah Tinggi Agama Islam Al-Azhary \\ Jl. Abdullah Bin Nuh, Kelurahan Pamovanan, Kec. Cianjur, Kabupaten Cianjur, \\ Jawa Barat, Indonesia, 43211 \\ Email: rudiahmad83@gmail.com

\begin{abstract}
Nurrohman
Faculty of Islamic Law, Universitas Islam Negeri Sunan Gunung Diati Bandung Jl. A.H. Nasution No.105, Cipadung, Kec. Cibiru, Kota Bandung, Jawa Barat, Indonesia, 40614

Email: nurrohman@uinsgd.ac.id
\end{abstract}

\begin{abstract}
The research aimed to analyze the study of Islamic law regarding slaughter and stunning, and provide an assessment of the benefits of the slaughter and slaughter results. The research method is a library study in which the process is by collecting book data and other reading sources. Data sources in the form of fiqh references and ICU fatwas, accompanied by empirical research findings on stunning. The main references are obtained from al-Figh al-Islami wa Adillatuhu, al-Haram wa al-Haram, Kasysyaf al-Qina', and several books of hadith and figh. The research found that stunning is permissible by paying attention to temporary fainting animals, does not cause death and permanent injury, aims to facilitate slaughter, and not to torture animals. Slaughter by conventional means is recommended. The benefit is based on the indicator that animals die faster. Opinions of Ulama and ICU Fatwa encourage the slaughter manually without stunning.
\end{abstract}

Keywords: Slaughtering; Stunning; Islamic Law; ICU Fatwa

How to Cite: Yani, A., Suryadi, R. A., \& Nurrohman, N. (2020). Stunning on Animals Slaughter on Islamic Law Perspective. Jurnal Ilmiah Al-Syir'ah, 18(1), 77-90.

Permalink/DOI: http://dx.doi.org/10.30984/jis.v18i1.1103

Copyright (C) 2020, Jurnal Ilmiah Al-Syir'ah 


\section{Jurnal Ilmiah Al-Syir'ah Vol. 18, No. 1 (2020): 77-90 \\ Website: http://journal.iain-manado.ac.id/index.php/JIS \\ ISSN 2528-0368 (online) ISSN 1693-4202 (print)}

\section{INTRODUCTION}

Based on a study by the Central Statistics Agency (CSA), beef demand for consumption and industry in Indonesia in 2012 amounted to 484,000 tons and in 2019 , it increased to 686,270 tons. Every year the demand will continue to increase along with the increase of population and high public interest in meat consumption. The high demand causes a high intensity of slaughter, so the existence of slaughterhouses as a place for slaughtering is urgently needed. In its implementation slaughterhouse must be able to maintain the quality of meat, both from the level of cleanliness, health, or halal meat (Ditjen PKH, 2019).

The Center for Tropical Animal Studies at Bogor Agricultural Institute on the application of stunning to the process of slaughtering cows. Validation of stunning success was associated with signs of death; about $98.16 \%$ of cows still showed rhythmic and non-rhythmic breathing movements, $99.1 \%$ showed no corneal reflexes and $99.1 \%$ still showed body movements. This study shows that the assessment of skull damage, stunning in West Java is still not able to meet the criteria of the Halal Assurance System (HAS) 23103, although it almost meets the requirements of the Indonesian National Standard (SNI) 99003 criteria. While from the aspect of animal welfare, the implementation of stunning has not been able to fully fulfill the implementation of animal welfare principles due to the lack of facilities, especially in the availability of restraining boxes with head and neck restraints, the availability of suitable cartridges and the skills of stunning officers.

The research conducted by Iham, all forms of stunning have an impact on reducing the quality of meat, and slaughtering without stunning turns out to be better, animals do not feel pain and blood can come out perfectly because the perfection of bleeding is a condition for good quality of meat produced. It can be interpreted that the animal slaughtered without stunning produces a better quality of meat for the body if they are consumed (Ilham, 2017). In the halal meat cutting process, it is believed to produce bleeding that is quite perfect, otherwise, it can be beneficial to extend the shelf life or guarantee of meat quality (Addean, Benjakul, Wattanchant, \& Maqsood, 2014).

All three studies show that halal slaughtering has resulted in the death of perfectly slaughtered animals. Slaughtering animals with manuals without stunning can guarantee the halal and quality of the meat consumed. These three studies have not been deeply related to the analysis of Islamic law. The establishment of Islamic law is considered important to justify the status of the meat consumed. Thus, the principle of halal meat is related empirically to the benefit, especially on the consequences of the law of halal slaughter. Research on the Islamic law side which is strengthened by the results of empirical studies can be used as a novelty in research on stunning slaughter.

In Indonesia, there are two methods before slaughter, they are stunning, and without stunning. The practice of slaughtering cows without stunning has been done for a long time in Indonesia. Slaughtering with stunning aims to get cows treated 


\section{Jurnal Ilmiah Al-Syir'ah Vol. 18, No. 1 (2020): 77-90 \\ Website: http://journal.iain-manado.ac.id/index.php/JIS \\ ISSN 2528-0368 (online) ISSN 1693-4202 (print)}

according to animal welfare, thereby minimizing stress to cows. Most of the slaughterhouses still use conventional methods by binding and pulling cows firmly until they fall to the floor and then slaughtered. Rough treatment in handling slaughtering will cause stress on animals and produce a low quality of meat. Animal handling during slaughter must be regulated properly to maintain standards because animal welfare is part of the quality of meat (Grandin, 2001). To minimize stress and pain in animals, especially cows, in some slaughterhouses, stunning is done before the animal is slaughtered (Pisetiyani \& Et.al, 2015).

On the other hand, Schulze and Hazem from Hanover University in Germany in 1978, found that stunned animals had pain more strongly than animals that are not stunned. The study was conducted with EEG (Electro Encephalo Graphy) and ECG (Electro Cardio Graphy). This research explained that when a slaughtered cow struggles and stretches muscles, it is not because of pain, but rather as an expression of muscle and nerve shock. This condition is in response to the severance of nerve impulses from the brain to the body (An Najah, 2012).

Animal slaughtering is a concern in Islam. Consumption of slaughtered meat refers to halal standards. In this case, Islamic law regulates slaughter based on nash and qaul al-ulama, which specifically discuss the rules and procedures that are appropriate according to the Shari'a. Also, scholars pay attention to the welfare of slaughtered animals. The rules, procedures, and attention to animal welfare become important references in the process of slaughtering animals, including the law of stunning.

The main focus of this research is the analysis of Islamic law and the strengthening of empirical facts about slaughter. The research aims to analyze the study of Islamic law regarding slaughter and stunning and to provide an assessment of the benefits of the slaughter and slaughter results, including slaughtering with a machine in which the size is according to the animal being slaughtered and recite bismillah for many animals slaughtered.

\section{RESEARCH METHODS}

The research used library research. The process is by collecting data from books and other reading sources. Data sources in the form of fiqh references and fatwas of the Indonesian Council of Ulama, accompanied by the results of empirical research on stunning. The main references are obtained from al-Figh al-Islami wa Adillatuhu, al-Haram wa al-Haram, Kasysyaf al-Qina', and several books of hadith and fiqh. Data is arranged based on problem formulation and processed into valid and objective data (Zed, 2010). All data were collected, edited, combined, extracted, and explained in a language understood by the reader. Analysis of the literature study will strengthen the findings of this research. 
Jurnal Ilmiah Al-Syir'ah Vol. 18, No. 1 (2020): 77-90

Website: http://journal.iain-manado.ac.id/index.php/JIS

ISSN 2528-0368 (online) ISSN 1693-4202 (print)

\section{RESULTS AND DISCUSSION}

\section{Stunning}

Stunning is a method used to facilitate the slaughter by stunning the animals first before being slaughtered. Technically, this method provides convenience, because the animals been stunned will not move, so the slaughterer is easier to do the job. Stunning is the process of removing the awareness and feelings of the slaughtered animal (Ilham, 2017).

The various methods are used according to the type of animal and treatment needs, including; The Captive Bolt Pistol (CBP) or Stunning Gun, Electric Head Only Stunning, Waterbath Stunning, and Gas Stunning. Based on the results of careful observation of several slaughterhouses, in practice, from the four stunning methods used, there are some doubts about its halal. Throughout the observation that the stunning gun results in skull permanent suffered injuries and the death of animals, even without slaughtering after stunning, thus specifically the stunning gun needs to be reviewed or to increase human resource skills as a stunning operator.

Slaughtering animals mechanically (stunning gun) is one of the technical terms in animal science widely practiced in slaughter. In short, the stunning gun is to shoot animals using a special bullet inserted into the gun shell, and pulled the trigger then the bullet explodes in a cylinder in which there is a piston that glides due to pressure from the bullet explosion, thus the outside of the gun will hit the part of nerve fibers resulting in loss of animals' consciousness, and these unconscious animals will be slaughtered. Through this treatment, animals do not feel too much pain due to slaughter (Authority, 2014).

The stunning method or slaughtering by weakening animals before being slaughtered was done because the need for meat continues to increase so this method is considered very helpful in the process of slaughter. The stunning method has been applied in many American, European, and Australian countries, including in Indonesia, providing a lot of convenience in slaughtering livestock, especially on a large scale. However, this method also causes risks in its halal, if it is not done properly (Ilham, 2017).

Westerners have their way of slaughtering animals (western method), it is by making the animals to be slaughtered faint, then slaughter them later (Ilham, 2017). Animals are considered fine to feel pain when slaughtered. Today there are many modern ways to make animals faint (Authority, 2014). 
Jurnal Ilmiah Al-Syir'ah Vol. 18, No. 1 (2020): 77-90

Website: http://journal.iain-manado.ac.id/index.php/JIS

ISSN 2528-0368 (online) ISSN 1693-4202 (print)

Table 1. Stunning type

\begin{tabular}{|c|c|c|}
\hline No & Way & Explanation \\
\hline 1 & $\begin{array}{l}\text { The Captive Bolt } \\
\text { Pistol }(C B P)\end{array}$ & $\begin{array}{l}\text { CBP is fired into the animal's skull, causing shocks to } \\
\text { the brain and making animals unconscious. Only after } \\
\text { that, the animal is slaughtered. }\end{array}$ \\
\hline 2 & $\begin{array}{l}\text { Electric Head-only } \\
\text { Stunning }\end{array}$ & $\begin{array}{l}\text { Electric head-only stunning clipped to the heads of } \\
\text { animals, usually cows, goats, or sheep. After being } \\
\text { clipped, the operator will conduct an electric that will } \\
\text { go directly through the brain and cause animals to lose } \\
\text { consciousness. }\end{array}$ \\
\hline 3 & $\begin{array}{l}\text { Waterbath } \\
\text { Stunning }\end{array}$ & $\begin{array}{l}\text { This method is commonly used to faint livestock such } \\
\text { as chickens, turkeys, ducks, or geese. The head of the } \\
\text { poultry is dipped in water that has been electrified. But, } \\
\text { poultry often dies when passing this method. }\end{array}$ \\
\hline 4 & Stunning gas & $\begin{array}{l}\text { In this technique, animals will be blown with } \mathrm{CO} 2 \text { gas } \\
\text { which makes animals lose consciousness, before } \\
\text { finally being slaughtered }\end{array}$ \\
\hline
\end{tabular}

Source: Welfare Aspects of Animal Stunning and Killing Methods (Authority, 2014).

Table 1 explains the stunning types used for the initial slaughter of animals. From the four stunning types, the stunning which do not cause injury and die before being slaughtered is permitted. In Indonesia, the method of the stunning cow using a captive bolt gun is not recommended. This is closely related to Islamic law. There are doubts about the halal status of cows stunned by this method.

If using bullets that are too large, there is a chance for the animal that will not only faint but immediately die. If that happens, the animal has become a carcass and the meat produced does not meet the halal rules. Conversely, if the power of the bullets used is too light, the animals will not faint, it will even become inflamed and malignant. They will struggle and put out their strength to rebel. The resulting meat is considered not halal because cows will be tortured before being slaughtered, these conditions also endanger workers or guards who will slaughter them (Authority, 2014).

Slaughter with stunning provides convenience, speed and safety in slaughtering, because animals tend not to move, can be slaughtered immediately, and will not wriggle or make movements that can endanger slaughterers (Ilham, 2017). Hamdan Rasyid (2013) mentioned two stunning goals. First, it removes the awareness and feelings of the animal to be slaughtered, so that, the animal does not feel pain during the slaughter. Second, it makes production work easier. It does not take long for the slaughter. If the slaughter does not use stunning, the production will decrease (Ilham, 2017). 


\section{Jurnal Ilmiah Al-Syir'ah Vol. 18, No. 1 (2020): 77-90 \\ Website: http://journal.iain-manado.ac.id/index.php/JIS ISSN 2528-0368 (online) ISSN 1693-4202 (print)}

In the results of one study, stunning is considered important because stress before slaughtering harms the quality of the meat produced. Stress before slaughter causes increase levels of catecholamines and creatine kinase in the body. The increased levels of catecholamines and creatinine kinase cause glycolysis quickly resulting in a buildup of lactic acid in meat. It also causes a decrease in glycogen levels which causes a high $\mathrm{pH}$ of meat and water holding capacity. Besides, the meat produced is harder with a darker color (Authority, 2014).

Hamdan Rasyid (2013), mentioned the slaughter with a stunning mechanism that can be seen in table 2:

\section{Table 2. Slaughtering Steps with Stunning}

\begin{tabular}{ll}
\hline Step & \multicolumn{1}{c}{ Treatment } \\
\hline 1 & Before being slaughtered, animals are stunned first \\
\hline 2 & $\begin{array}{l}\text { After being stunned, the animal remains alive (animate) so that if it is } \\
\text { not slaughtered it can still live normally. }\end{array}$ \\
\hline 3 & $\begin{array}{l}\text { After being stunned, the animal is just cut using a sharp knife so that it } \\
\text { can break the respiratory track (hulqum), food channels (mari'), and } \\
\text { two neck veins (wadajain). }\end{array}$ \\
\hline 5 & $\begin{array}{l}\text { Slaughtering of animals is carried out by Muslim slaughterer and recite } \\
\text { basmalah first }\end{array}$ \\
\hline & $\begin{array}{l}\text { After being cut and the blood has stopped flowing, the animal's bowels } \\
\text { are all removed, and then the meat is cut into pieces. }\end{array}$ \\
\hline
\end{tabular}

Source: Indonesian Fiqh Actual Fatwa Association (Rasyid, 2013).

The process of slaughtering animals with stunning can be done through the process as in table 2. Animals are ensured alive after the stunning process. Animals are slaughtered with a sharp knife while still observing the elements of Shari'a and animal welfare.

\section{The perspective of Islamic Law on Slaughtering}

Slaughter is the process of cutting by flowing blood through the cutting of food channels (mari'/ esophagus), respiratory tract/throat (hulqum / trachea), and two blood vessels (wadajain / jugular veins and artericarotids) (Solek, 2013). In this case, Islam regulates people to slaughter animals first that will be consumed. Because, the meat taken from live animals is haram according to the shari'a (Solek, 2013).

In this context, slaughtering animals is not the same as kill. Killing animals can be done in various ways, such as being hit, struck with weapons, doused with hot water, or burned. But these methods are not exemplified by the Prophet and including cruel acts. The definition of slaughtering animals is to cut off the path of eating, drinking, breathing, and veins on the neck of the animal being slaughtered using a knife, sword, or other sharp instruments following the provisions of the 


\section{Jurnal Ilmiah Al-Syir'ah Vol. 18, No. 1 (2020): 77-90 \\ Website: http://journal.iain-manado.ac.id/index.php/JIS \\ ISSN 2528-0368 (online) ISSN 1693-4202 (print)}

shari'a. Etymologically slaughter means to cut, divide, or kill an animal. While in terminology, there are differences of opinion among the schools of fiqh, according to their differences about the part that must be cut in the slaughter (Al-Sa'di \& Et.al, 2010).

The Hanafi and Maliki schools mention that slaughtering is the act of cutting the veins of life of animals, which are four veins: throat, esophagus, and two large veins located on the side of the neck. The location of the slaughter is the part between the bottom of the neck and where the beard grows, which is the lower jaw bone. Meanwhile, slaughter on Shafi'I's and Hanbali's point of view is the act of slaughtering certain animals which may be eaten by cutting the throat and esophagus. The position and location of the cut can be at the top of the neck or the bottom of the neck, or in situations that do not allow slaughtering in the neck or carried out deadly stabbing in any part of the animal's body (Al-Zuhaili, 2011).

Slaughter (al-dzakiyat) is a way that can justify an animal for consumption which is done by piercing the animal's neck to death (nahr), slaughtering, or by injuring. The nahr is the slaughter carried on the camel. As for animals other than camels is by slitting the neck (slaughtered) or by injuring animals that are not possible to lose their lives except by injuring it (Al-Utsaimin, 2013).

Slaughtered animals must be halal animals and may be eaten, for example, cows, buffaloes, goats, and chickens. If the animal being slaughtered is a forbidden animal, like a pig, even though it is slaughtered in the name of Allah, the animal is still forbidden to eat. In other words, the animal's status does not turn into halal even though it has been slaughtered according to sharia (RI, 2012). In Indonesia, instructions on halal slaughter are affirmed in ICU Fatwa Number 12 of 2009 concerning Halal Slaughtering Standards issued on 15 Dzulhijjah $1430 \mathrm{H} / 2^{\text {nd }}$ December 2009 (Solek, 2013).

The main thing to note is regarding the terms and conditions of slaughter. Yusuf Al-Qardawi (2010) mentioned in the book al-Halal wa al-Haram fi al-Islam regarding the conditions for slaughter: 1) animals must be slaughtered or stabbed (nahr) with a sharp instrument that can drain blood and take the life of the animal, whether it is stone or wood; 2) Slaughter or stabbing (nahr) must be carried out on the neck of the animal with the severing of the arteries or esophagus; 3 ) no other name is called beside Allah, and 4) mentioning Allah's name. (recite basmalah).

Also, the ICU fatwa stipulates that the standards for animals that can be slaughtered are: 1) Animals that are slaughtered are animals that can be eaten; 2) Animals must be alive when slaughtered; 3) Animal conditions must meet animal health standards set by authorized institutions. The standard of slaughter in the ICU fatwa must be a Muslim and has a legal age, understands the procedures for slaughter according to the Shari'a, and has expertise in slaughter (Solek, 2013). 


\section{Jurnal Ilmiah Al-Syir'ah Vol. 18, No. 1 (2020): 77-90 \\ Website: http://journal.iain-manado.ac.id/index.php/JIS \\ ISSN 2528-0368 (online) ISSN 1693-4202 (print)}

\section{Empirical Facts of Findings}

Findings are related to perfect death based on the time of the blood stops emanating in slaughtered cows. Herwin Pisetiyani examined this in 2015. The object of research used in his research was the Brahman Cross cows. The total number of cows observed in the calculation of blood-stopping times was 30, divided into 2 groups, 15 of which were slaughtered first with stunning and 15 slaughtered without passing through the process of stunning (Pisetiyani \& Et.al, 2015).

The results of this study indicate a significant difference in blood stopping time $(\mathrm{p}<0.05)$ in cows slaughtered with stunning and without stunning. The average blood stop time radiating stunned before being slaughtered was 3.02 minutes while the maximum blood stop time was 4.33 minutes and a minimum of 1.53 minutes. While the time needed for blood to stop slaughtered without stunning first has an average value of 2.13 minutes with a minimum blood stopping time of 1.04 minutes and a maximum of 3.14 minutes. The difference in blood stop time between cows that were stunned and not stunned before being slaughtered was 53.4 seconds (Pisetiyani \& Et.al, 2015).

The cows stunned before being slaughtered require a longer blood stop than they that are not stunned. The stopping time of blood is influenced by the treatment of animals before slaughter.

The cows slaughtered without stunning process are fixed using a restraining box mark IV. Grandin said a restraining box is a device used to control cows before being slaughtered so that stress levels in cows are reduced. In principle, the stress level can be reduced because (1) when the cow enters the restraining box, the cow does not feel afraid because it is protected from the environmental influence of the slaughtering area, this is important especially for the cow that is quite aggressive; (2) to overcome the hacked head of the cow because the view around is fully closed; (3) makes it easy to knock down a cow without harsh treatment; (4) the stability of this tool makes the cow calmer and overcomes sudden rebel movements; and (5) tool pressure on cow does not cause pain and is rapid (Grandin, 2001). In principle, stress levels can be reduced because of the movement of fine tools, have a low noise level, tool pressure on cows does not cause pain, and cows do not feel afraid because they avoid the environmental influence of the slaughtering area (Pisetiyani \& Et.al, 2015).

The results of this study indicate that the perfect dead for a cow with a stunning method is 3.02 minutes while the cow slaughtered with the method without stunning/conventional is 2.13 minutes. This is based on the time when blood stops gushing out after being slaughtered. Cows slaughtered without stunning die faster than stunning. 


\section{Jurnal Ilmiah Al-Syir'ah Vol. 18, No. 1 (2020): 77-90 \\ Website: http://journal.iain-manado.ac.id/index.php/JIS ISSN 2528-0368 (online) ISSN 1693-4202 (print)}

\section{The perspective of Islamic Law on Stunning}

In the context of the codification of Islamic law (fatwa) in Indonesia, stunning is one of the important studies. This is evidenced by the ICU fatwa number 12 of 2009 concerning Halal Slaughter Certification Standards. This fatwa is motivated by several things. First, the practice of slaughtering animals in Islam must follow procedures by the provisions of Islamic law, hence it can be consumed by Muslim communities. Second, the implementation of animal slaughtering processes today, many abattoirs utilize modern equipment in line with technological developments, so that there are various models of slaughtering and processing that raise questions regarding the suitability of the implementation of slaughter with Islamic law. Some of the bases in al-Qur'an are mapped in table 3:

Table 3. Codification of verses of the Koran regarding Slaughter

Al-Qur'an "Prohibited to you are dead animals, blood, the flesh of swine,
and that which has been dedicated to other than Allah, and [those
animals] killed by strangling or by a violent blow or by a head-
long fall or by the goring of horns, and those from which a wild
animal has eaten, except what you [are able to] slaughter [before
its death], and those which are sacrificed on stone altars, and
[prohibited is] that you seek decision through divining arrows.
That is grave disobedience"(Surah Al-Maidah [5]: 3)

"And do not eat of that upon which the name of Allah has not been mentioned, for indeed, it is grave disobedience. And indeed do the devils inspire their allies [among men] to dispute with you. And if you were to obey them, indeed, you would be associators [of others with Him]."'(Surat al-An'am [6]: 121)

"who enjoins upon them what is right and forbids them what is wrong" (Surah Al-A'raf [7]: 157)

"Lawful for you are the animals of grazing livestock except for that which is recited to you" (Surat al-Maidah [5]: 1)

"And the grazing livestock He has created for you; in them is warmth and [numerous] benefits, and from them you eat" (Surat al-Nahl [16]: 5) 
Jurnal Ilmiah Al-Syir'ah Vol. 18, No. 1 (2020): 77-90

Website: http://journal.iain-manado.ac.id/index.php/JIS

ISSN 2528-0368 (online) ISSN 1693-4202 (print)

Some verses of al-Qur'an in table 3 explain the halal principle of animals. One of them is determined by the slaughter of animals. The halal slaughter of animals follows the shari'a rules associated with the name of Allah. The basis of the traditions referred to are as follows:

Table 4. Codification of Hadith regarding Slaughter

\begin{tabular}{|c|c|c|}
\hline No & Reference (Book) & Content Structure (Matn al-hadith) \\
\hline \multirow[t]{3}{*}{1} & $\begin{array}{l}\text { The Sahih Muslim juz } 3 \\
\text { pages } 1548 \quad \text { hadith } \\
\text { number } 1955 .\end{array}$ & \multirow{3}{*}{$\begin{array}{l}\text { From Syidad bin Aus ra that the Prophet said: } \\
\text { "Verily Allah has enjoined goodness to } \\
\text { everything; so when you kill, kill in a good way } \\
\text { and when you slaughter, slaughter in a good way. } \\
\text { So every one of you should sharpen his knife, and } \\
\text { let the slaughtered animal die comfortably." }\end{array}$} \\
\hline & $\begin{array}{l}\text { Sahih Ibn Hibban juz } \\
13,199\end{array}$ & \\
\hline & $\begin{array}{l}\text { Imam al-Turmudzi in } \\
\text { Sunan al-Turmudzi juz } \\
4,23 \text { ) }\end{array}$ & \\
\hline 2 & $\begin{array}{l}\text { Musnad Ahmad juz 4, } \\
142 \text { (HR. Jama'ah) }\end{array}$ & $\begin{array}{l}\text { "From Rafi 'bin Khudaij ra he said: The } \\
\text { Messenger of Allah said:" (Animals slaughtered } \\
\text { with) a device that drains blood and is called the } \\
\text { name of Allah upon it so eat, as long as the tool is } \\
\text { not teeth and nails. Teeth (forbidden) because } \\
\text { they are bone while nails are the cutting tool of } \\
\text { the Habasyah" }\end{array}$ \\
\hline 3 & $\begin{array}{l}\text { Sunan al-Baihaqi al- } \\
\text { Kubra juz 9, } 278\end{array}$ & $\begin{array}{l}\text { "From Abi Umamah al-Bahily ra that the } \\
\text { Messenger of Allah said: (Allowed as a means of } \\
\text { slaughtering) every tool that cuts veins as long as } \\
\text { not fangs or nails" }\end{array}$ \\
\hline \multirow[t]{3}{*}{4} & Musnad Ahmad juz 2, & \multirow{3}{*}{$\begin{array}{l}\text { From Abdillah bin Umar r.a said: The } \\
\text { Messenger of Allah commanded to sharpen a } \\
\text { knife (a tool to slaughter) and hide it from cattle } \\
\text { (to be slaughtered)" }\end{array}$} \\
\hline & & \\
\hline & $\begin{array}{l}\text { Sunan al-Baihaqi al- } \\
\text { Kubra juz 9, } 280\end{array}$ & \\
\hline 5 & $\begin{array}{l}\text { Sahih al-Bukhari juz } \\
3.1391 \text { number hadith } \\
\text { 3614. }\end{array}$ & \multirow{2}{*}{$\begin{array}{l}\text { From Abdillah Ibn Umar ra that the Prophet met } \\
\text { with Zaid bin 'Amr bin Nufail near Baldah before } \\
\text { the revelation, then served food (in the form of } \\
\text { meat) to the Prophet, but he was reluctant to eat it } \\
\text { and then said: "Surely I do not eat the meat that } \\
\text { you slaughtered for your idols. I do not eat food } \\
\text { that is not called by Allah's name on it. }\end{array}$} \\
\hline 6 & $\begin{array}{l}\text { al-Sunan al-Kubra li al- } \\
\text { Nasa'i juz 5, } 55 \text { hadith } \\
\text { number } 8189\end{array}$ & \\
\hline
\end{tabular}

Source: ICU Fatwa Number 12 of 2009 concerning Halal Slaughter Certification Standards (MUI, 2014). 


\section{Jurnal Ilmiah Al-Syir'ah Vol. 18, No. 1 (2020): 77-90 \\ Website: http://journal.iain-manado.ac.id/index.php/JIS \\ ISSN 2528-0368 (online) ISSN 1693-4202 (print)}

The Hadith presented in table 4 teaches every Muslim to do good, including the process of slaughtering animals. Animals are treated well with a sharp knife preparation before the slaughter process. Hadiths forbid slaughter with nails or fangs. Besides, the slaughtered animal is associated with the mention of Allah's name. The above description shows that the basis of nash consists of 5 verses of alQur'an and 5 hadiths. The hadith is referred to from several books which are muktabar and muktamad.

Slaughter through stunning first, also discussed by several scholars, both classical and contemporary. The reference gives a clue about the stunning by looking at 'ibarat al-nash side. In the aspect of the derivation of Islamic law theory based on the verse al-ahkam, Imam al-Qurthubi (2010) explained that the scholars differed on how legitimate the slaughter was. According to jumhur ulama that every tool that can cut the veins and bleed is included as a means of slaughter besides teeth and nails. This opinion is supported by atsar.

In connection with the validity of the nine must say basmalah, al-Bahuty (2012) in one of his books, Kasysyaf al-Qina', stated: "The basis for having to say the name of Allah, when slaughtering is His word," And do not eat the animals that are not called the name of Allah SWT when slaughtering it. Indeed such acts are wickedness "Fisq is haram. The Prophet when slaughtering also mentions the name of Allah. It was said that recite takbir accompanied the mention by saying Bismillahi Wallahu Akbar, as the hadith of the Prophet (PBUH) said when he slaughtered, so did Ibn Umar, Bismillah is enough."

In addition to this, related to animals slaughtered and not yet totally dead marked by body movements, Ibn Qudamah (2010) stated (qaul) that if an animal has been slaughtered moves and has not died and then falls into water or something falls on it, the animal is not eaten, it is something that generally caused death. This opinion is what Imam al-Kharqi mentioned as Imam Ahmad's opinion. Meanwhile, most mutaakhirin ulama, the followers of Hanbali stated that this is not haram. Such is the view of the majority of jurists.

Ibn Qudamah's explanation was strengthened by statements if the cattle had been slaughtered, it is sentenced to death. Likewise, if it beheaded after slaughtering the law is not haram, as the view of Imam Ahmad bin Hanbal. The foundation of Imam al-Kharqi is the hadith narrated by Imam'Adibin Hatim "When animals fall into water then do not eat". Ibn Mas'ud also stated "Whoever throws a bird (for hunting) then falls into the water and drowns, do not eat it because the drown (could be) causes death. If they are mixed because of drowning and slaughter, it means they are combined with what is permissible to eat and haram. In this condition, haram is won. Also, there is no guarantee of a cause that determines death. It could be the death of two activities: the permissible and the haram. This is similar to the existence of two actions (subjects) in one thing (objects) or if there is (game) thrown by Muslims and the majus then dies (Qudamah, 2010). 


\section{Jurnal Ilmiah Al-Syir'ah Vol. 18, No. 1 (2020): 77-90 \\ Website: http://journal.iain-manado.ac.id/index.php/JIS \\ ISSN 2528-0368 (online) ISSN 1693-4202 (print)}

The condition for animals being slaughtered must be ensured that there is still strong movement after cutting the respiratory tract and food channel (al-hayah al-mustaqirrah). This explanation is stated by al-Syarbini (2012) in al-Iqna', which states that al-hayah al-mustaqirrah's sign is a strong movement after cutting the respiratory tract and food channel according to a more valid opinion in al-Zawa'id and al-Majmu' (Al-Nawawi, 2010). This is confirmed by Imam al-Nawawi (2010) in Raudhah al-Thalibin, the signs of al-hayah al-mustaqirrah are the existence of strong movements after cutting the respiratory tract, food, and the spreading of blood.

Some of the opinions of scholars above are included in statements in classical literature but have 'ibarat al-nash which can be linked to current operational practices. The statement of contemporary scholars refers to mechanical slaughter include Wahbah al-Zuhaili's opinion. According to him, there is no obstacle to using facilities weaken the movement of animals without torturing them (for slaughtering animals). For this reason, in Islam, it is permissible to use modern stunning methods which are not deadly before the slaughter (Al-Zuhaili, 2011).

This statement by al-Zuhaili (2011) provided an opportunity for understanding that the practice of stunning is permissible. The condition is that the practice does not kill animals before slaughter. Al-Zuhaili (2011) did not mention muqayyad for the stunning type, but only reinforces the statement of his permissibility principle as long as it does not kill animals before slaughter.

Paying attention to the statements of several related parties is also to strengthen the legal explanation. The enactment of the ICU Fatwa Number 12 of 2009 concerning Halal Slaughter Certification Standards by the Fatwa of the Indonesian Council of Ulama on Mechanical Slaughter of Animals on October 18, 1976; Decree of the Coordination Meeting of the Fatwa Commission and ICU's LPPOM and the Indonesian Department of Religious Affairs, on May 25, 2003, in Jakarta; Indonesian Council of Ulama Fatwa Number 4 of 2003 concerning Halal Fatwa Standardization; The Results of the Ijtima' of Ulama Decree of the Indonesian Fatwa Commission II of 2006 at Gontor Ponorogo Islamic Boarding School on Critical Issues in Halal Audit; Results of the ICU Fatwa Commission Working Group Meeting on Food, Medicine, and Cosmetics and the ICU LPPOM Team on November 12, 2009.

This fatwa produces decisions, one of which relates to stunning. Stunning to simplify the process of slaughtering animals is legal, provided that: (1) Stunning only causes animals to faint temporarily, does not cause death and permanent injury; (2) aims to facilitate the slaughter; (3) its implementation as a form of ihsan, not to torture animals.

The ICU fatwa did not mention the stunning type used, similarly al-Zuhaili's opinion above. The principle statement is not to cause death and permanent injury and is supported by evidence that the equipment used is under the provisions (the form of ihsan, not to torture animals). 


\section{CONCLUSION}

Animals slaughtered in sharia rules are treated well, preparing sharp knives, and reciting the name of Allah. Stunning is allowed by paying attention to animal welfare and the establishment of al-hayah al-mustaqirrah, as stated by ICU scholars and Fatwa Number 12 of 2009 concerning Halal Slaughtering Certification Standards. The results of empirical studies show that conventional slaughtered are recommended because cows die faster so they do not feel pain longer.

\section{ACKNOWLEDGMENTS}

Thank you to the Indonesian Council of Ulama (ICU) of Cianjur Regency and Islamic College of al-Azhary Cianjur, which has encouraged us to investigate the main theme of the slaughtering of Islamic legal perspectives. Hopefully, the results of this study will be a scientific contribution for researchers and observers of Islamic law to be further developed in other studies.

\section{REFERENCES}

Addean, A., Benjakul, S., Wattanchant, S., \& Maqsood, S. (2014). No TitleEffect Of Islamic Slaughtering On Chemical Compositions And Post-Mortem Quality Changes Of Broiler Chicken Meat. International Food Research Journal, 21(3), 897-907.

Al-Bahuty. (2012). Kasysyaf al-Qina’. Mesir: Dar al-'Ilmiyyah.

Al-Khatib, A.-S. (2012). al-Iqna. Beirut: Dar al-Fikr.

Al-Nawawi. (2010). Raudlah al-Thalibin. Mesir: Dar al-'Ilmiyyah.

Al-Qardhawi, Y. (2010). al-Halal wa al-Haram fi al-Islam. Beirut: Dar al-Fikr.

Al-Qurthubi, I. (2010). Tafsir al-Qurthubi. Beirut: Dar al-Fikr.

Al-Sa'di, S. A., \& Et.al. (2010). Fiqh al-Bay'Wa al-Syira'. Arab Saudi: Maktabah Madinah.

Al-Utsaimin, M. bin S. (2013). Tatacara Qurban Tuntunan Nabi. Yogyakarta: Media Hidayah.

Al-Zuhaili, W. (2011). al-Fiqh al-Islami wa Adillatuhu. Beirut: Dar al-Fikr.

An Najah, A. Z. (2012). Makanan Haram dan Asam Urat. Bekasi: Bekam Group.

Authority, E. F. S. (2014). Welfare Aspects of Animal Stunning and Killing Methods. In Scientific Report Of The Scientific Panel For Animal Health EFSAQ-2003-093 (pp. 495-507). Italy: Efsa Report. 
Jurnal Ilmiah Al-Syir'ah Vol. 18, No. 1 (2020): 77-90

Website: http://journal.iain-manado.ac.id/index.php/JIS

ISSN 2528-0368 (online) ISSN 1693-4202 (print)

Ditjen PKH, D. J. P. dan K. H. (2019). Supply Demand Daging Sapi/Kerbau Sampai Dengan Desember 2019. Jakarta: Ditjennak dan Keswan.

Grandin, T. (2001). Antemortem Handling and Welfare. In H. Y. H. (Ed.), Meat Science and Applications. New York: Marcel Dekker.

Ilham. (2017). Analisis Perbandingan Terhadap Sistem Penyembelihan Hewan Secara Stunning dengan Manual. Makassar: UIN Alauddin Makassar.

MUI, M. U. I. (2014). Fatwa MUI Nomor 12 Tahun 2009 tentang Standar Sertifikasi Penyembelihan Halal. Jakarta: Komisi Fatwa MUI.

Pisetiyani, H., \& Et.al. (2015). Kesempurnaan Kematian Sapi setelah Penyembelihan dengan dan tanpa Pemingsanan Berdasarkan Parameter Waktu Henti Darah Memancar. Jurnal Acta Veterinaria Indonesiana, 3(2), 58-63.

Qudamah, I. (2010). al-Mughni. Beirut: Dar al-Fikr.

Rasyid, H. (2013). Fiqih Indonesia Himpunan Fatwa-Fatwa Aktual. Jakarta: PT. Almawardi Prima.

RI, D. A. (2012). Pedoman dan Tata Cara Pemotongan Hewan secara Halal. Jakarta: Ditjen Bimas Islam.

Solek. (2013). Juru Sembelih Halal Berbasis Pada Walisongo Halal Research Center (WHRC). Jurnal Dimas, 17(2), 289.

Zed, M. (2010). Metode Penelitian Kepustakaan. Jakarta: Pustaka Obor. 